\title{
SENSE OF PLACE KAWASAN WISATA PASAR UBUD
}

\author{
Melania Rahadiyanti ${ }^{*}$, Astrid Kusumowidagdo², Dyah Kusuma Wardhani3, \\ Thomas Stefanus Kaihatu ${ }^{4}$, Ida Ayu Indira Swari ${ }^{5}$ \\ 1, 2, 3 Program Studi Arsitektur Interior, Fakultas Industri Kreatif, Universitas Ciputra, \\ Citraland CBD Boulevard, Surabaya \\ 4, 5 Program Studi Bisnis Hospitaliti - Pariwisata, Fakultas Pariwisata, Universitas Ciputra, \\ Citraland CBD Boulevard, Surabaya \\ e-mail: *1 melania.rahadiyanti@ciputra.ac.id, 2astrid@ciputra.ac.id,

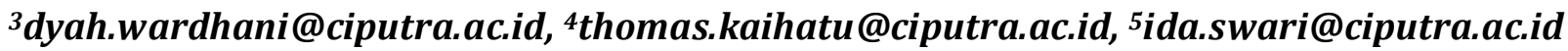

\begin{abstract}
Abstrak_ Kawasan Pasar Ubud telah menjadi daya tarik tersendiri sebagai tujuan wisata di Bali. Penelitian ini ingin menelaah lebih jauh persepsi pengunjung terhadap service-scape di kawasan wisata Pasar Ubud. Adapun penelitian eksploratif ini merupakan penelitian kualitatif dengan metode studi kasus. Metode pengumpulan data menggunakan interview mendalam, observasi dan dokumentasi. Objek penelitian yaitu Pasar Ubud dan koridor Jalan Karna yang berada di kawasan yang berdekatan. Pada kawasan Pasar Ubud, hasil penelitian menunjukkan faktor fisik yang berpengaruh pada sense of place-nya yaitu arsitektur, kawasan, barang dagangan, vocal point, dan area berdagang dengan mobil bak terbuka. Sedangkan faktor sosialnya berupa histori, simbol pohon beringin, karakter pedagang dan pengunjung, serta aktivitas perdagangan dan transisi. Pada kawasan Jalan Karna, faktor fisik pembentuk sense of place-nya yaitu arsitektur, kawasan, urban interior, barang dagangan, dan vocal point Sedangkan faktor sosialnya yaitu memori dan karakter pedagang serta pengunjung.
\end{abstract}

Kata kunci : Faktor Fisik; Faktor Sosial; Jalan Karna; Pasar Ubud; Sense of Place.

\begin{abstract}
The Ubud Market area has become the main attraction as a tourist destination in Bali. This study wants to examine further the perception of visitors to service-scape in the tourist area of Ubud Market. The exploratory research is a qualitative study with a case study method. Methods of collecting data using in-depth interviews, observation and documentation. The research objects are the Ubud Market and the Jalan Karna corridor in the adjacent area. In the Ubud Market area, the results of the study show that physical factors that influence the sense of place, namely architecture, area, merchandise, focal points, and areas of trading with pickup trucks. While the social factors are history, the symbol of the banyan tree, the character of traders and visitors, and trade and transition activities.
\end{abstract}

Keywords : Physical Factors; Social Factors; Karna Street; Ubud Market; Sense of Place.

\footnotetext{
${ }^{1}$ Program Studi Arsitektur Interior, Fakultas Industri Kreatif, Universitas Ciputra, Citraland CBD Boulevard, Surabaya ${ }^{2}$ Program Studi Arsitektur Interior, Fakultas Industri Kreatif, Universitas Ciputra, Citraland CBD Boulevard, Surabaya

${ }^{3}$ Program Studi Arsitektur Interior, Fakultas Industri Kreatif, Universitas Ciputra, Citraland CBD Boulevard, Surabaya

${ }^{4}$ Program Studi Bisnis Hospitaliti - Pariwisata, Fakultas Pariwisata, Universitas Ciputra, Citraland CBD Boulevard, Surabaya

${ }^{5}$ Program Studi Bisnis Hospitaliti - Pariwisata, Fakultas Pariwisata, Universitas Ciputra, Citraland CBD Boulevard, Surabaya
} 


\section{PENDAHULUAN}

Setiap pasar memiliki keunikan tempat, yaitu spirit of place dan sense of place-nya. Sangat penting bagi kita untuk dapat mempertahankan hal tersebut. Maka dari itu pengenalan akan kelebihan dan kekurangan dari sebuah tempat, terutama pasar di kawasan wisata, sangat penting untuk dianalisis, agar terdapat keberlanjutan sense of place dari tempat tersebut.

Salah satu objek wisata terkenal di Bali adalah kawasan pasar seni dan tradisional Ubud. Di kabupaten Gianyar sendiri ada tujuh pasar yang terdaftar, beberapa diantaranya menjadi objek wisata, seperti Pasar Sukawati dan Pasar Ubud. Pasar-pasar ini menjadi objek wisata karena keunikannya. Pasar Ubud merupakan pasar yang ketiga terbesar se-Kabupaten Gianyar. Seiring dengan perkembangan jaman, pasar ini terbagi menjadi dua sesi setiap harinya. Pasar pagi menjual sayur dan pasar siang hingga sore menjual barang-barang seni. Pasar Ubud ini juga menarik dari segi lokasi karena berada tepat di daerah utama kawasan wisata Ubud, yang terdapat objek wisata Puri Saren Agung, yaitu istana kerajaan Ubud. Di kawasan ini unsur budaya Bali masih sangat kental terasa, dapat dilihat dari ciri khas bangunan yang berornamen ukiran Bali, adanya tempat sembahyang yaitu Pura, dan perlengkapan sembahyang bagi umat beragama Hindu di sekitar kawasan. Dari kekhasan tersebut, dapat dilihat bahwa kawasan Pasar Ubud memiliki karakter tersendiri yang menimbulkan sense of place pada kawasan tersebut. Sense of place ini penting untuk dipertahankan agar tetap terjaga kelestarian kawasannya, terutama dalam memberikan identitas yang kuat bagi daerah Ubud pada khususnya, dan Bali pada umumnya.

Penelitian terdahulu mengenai sense of place telah banyak dilakukan di berbagai area (Najafi and M 2011). Jika dikaitkan dengan penelitian ini telah ada eksplorasi sense of place pada area komersial terutama toko dan shopping mall (Kusumowidagdo, Sachari, and Widodo 2015; Cross 2000; D’Astous 2000) koridor komersial (Kusumowidagdo, Sachari, and Widodo 2015), area atrium (Kusumowidagdo, Sachari, and Widodo 2016) foodcourt, restoran dan bentuk-bentuk lainnya (Astuti and Hanan 2011; Astuti and Hanan 2011; Kusumowidagdo, Sachari, and Widodo 2017) koridor komersial kawasan wisata religi (Kusumowidagdo, Sachari, and Widodo 2017) serta koridor jalan yang unik (Wardhani and Kusumowidagdo 2018). Dari beberapa penelitian di atas, masih sedikit penelitian yang membahas mengenai sense of place kawasan belanja tradisional yang memiliki identitas kuat. Maka dari itu penelitian ini akan mengisi celah dengan melakukan eksplorasi terhadap faktor fisik dan sosial yang membentuk sense of place kawasan Pasar Ubud. Penelitian ini dapat berfungsi untuk menjadi dasar langkah pelestarian dan peningkatan kualitas area ini di masa depan.

\section{Latar Belakang Teori}

Najafi and M (2011) mengemukakan ada dua hal yang mempengaruhi sense of place, salah satunya manusia, kemampuan kognitif dan faktor persepsi, sebagai pengamat. Sebagai penghuni tempat, identitas manusia juga menentukan identitas dari tempat (Schulz 1979). Selain manusia, karakteristik spasial dari penataan fisik juga merupakan hal yang penting, terutama pada lingkungan buatan atau bentuk arsitektur. Oleh sebab itu, dapat disimpulkan bahwa pembentuk sense of place dapat berupa faktor fisik, yakni bentuk fisik tempat, dan faktor sosial, yakni aktivitas manusia yang menjadi identitas sebuah tempat.

\section{Teori Faktor Fisik Sense of Place}

Kusumowidagdo, Sachari (Kusumowidagdo, Sachari, and Widodo 2012), dalam penelitiannya mengungkapkan bahwa faktor fisik yang berpengaruh terhadap sense of place kawasan perbelanjaan yaitu arsitektur (landscape, parking, material, signboard, form and scale) dan interiornya (form and finishing planes, thematic zoners, tenant spaces, lighting, zoning dan grouping, seating area, scale of public area). 
Beberapa unsur lain dalam membentuk sense of place adalah scent dan penghawaan. Scent memiliki pengaruh terhadap pengunjung (Baker 2000); (J, E, and C 1995); (D'Astous 2000); Penghawaan buatan penting untuk kenyamanan pengunjung (Kramer 2008); (Boon 2011); terutama pada temperatur, kelembaban, dan sirkulasinya (Baker 2000); (D'Astous 2000). Signage memberikan kejelasan penunjuk arah (Baker 2000; D'Astous 2000; Wee dan Tong, 2007; Boon 2011). Area duduk memberikan kenyamanan bagi pengunjung untuk dapat beristirahat (Baker 2000).

\section{Teori Faktor Sosial Sense of Place}

Indikator-indikator dari faktor sosial yang dipikirkan adalah kerumunan dan kepadatan pengunjung (Bell et al. 1997) pengunjung lain dengan gaya hidup yang sesuai (Baker 2000); (D'Astous 2000); (Astuti and Hanan 2011), jumlah pengunjung dan perilakunya ((Baker 2000); (D’Astous 2000).

\section{Teori Sense of Place Koridor}

Pada koridor bawah tanah, faktor-faktor yang kerap muncul dalam diskusi yaitu kualitas tempat (kesan hidup, hangat, menarik), lebar koridor, penggunaan warna, kejelasan ruang arsitektur, tingkat dan kualitas pencahayaan, ketinggian langit-langit dan panjang koridor. (Zacharias 1997); (Zacharias 2002); (Wardhani and Kusumowidagdo 2018).

Pada Koridor Pusat Belanja (Kusumowidagdo, Sachari Widodo, 2015; Kusumowidagdo dan Kusuma Wardani 2018)

Faktor sosial, antara lain image dan interaksi sosial, terasa dalam gaya hidup pengunjung, kepadatan kerumunan, dan kesamaan etnis serta segmen pengunjung. Faktor fisik di salah satu lokasi penelitian tersebut adalah harmoni visual dan suasana. Harmoni visual yang jelas dirasakan oleh para pengunjung yaitu konektivitas visual ketika berjalan di koridor yang terbentuk dari keharmonisan desain toko, tampilan toko, windows display, dimensi koridor, dan pemandangan yang bagus ke semua arah. Suasana koridor yang mendukung pengalaman berbelanja terbentuk melalui suhu yang sesuai, kontrol musik, dan kebersihan.

\section{Pada Koridor Kawasan Wisata Religi}

Faktor sosial yang ditemukan di kawasan Ampel yaitu narasi atau sejarah dan memori, kepadatan, suasana religius, atribut gaya hidup, interaksi dan aktivitas, dan eksistensi pedagang Arab (Kusumowidagdo, Sachari, and Widodo 2017). Faktor fisiknya meliputi pencahayaan, dimensi koridor, dan ketidakteraturan ruang komersil, faktor-faktor yang membedakan yaitu ornamen pada langit-langit, jalan yang menghubungkan ke permukiman, dan keteraturan ruang komersial. (Kusuma Wardhani dan Kusumowidagdo, 2017; Kusumowidagdo dan Kusuma Wardhani, 2018)

\section{METODE PENELITIAN}

Penelitian menggunakan metode kualitatif, dalam hal ini studi kasus. Kasus yang digunakan sebagai objek studi merupakan kasus tunggal. Menurut Yin (2011), kasus tunggal dapat digunakan untuk objek-objek yang dapat mewakili fenomena yang akan diteliti. Pengumpulan data menggunakan interview mendalam, observasi dan dokumentasi. Dari data yang diperoleh, akan dilakukan analisis untuk menarik kesimpulan (Yin 2011) faktor-faktor pembentuk sense of place pada objek studi kasus dalam penelitian ini.

Pada penelitian ini, perolehan data didapat dengan wawancara terhadap beberapa informan, diantaranya pegawai Kantor Pasar Ubud, akademisi dan pengamat kawasan Ubud, penduduk lokal 
Ubud, dan beberapa pengunjung. Topik wawancara meliputi sejarah dan perkembangan Pasar Ubud dan kekhasan Pasar Ubud dilihat dari faktor fisik dan sosialnya. Selain wawancara, juga dilakukan pengamatan visual serta dokumentasi untuk memperoleh data visual.

\section{Objek Penelitian}

Objek penelitian ini adalah kawasan Pasar Ubud. Sebenarnya batas pasar sendiri hanya pada bangunan pasar sampai dengan pura pasar. Daerah di luar batas pasar merupakan kawasan permukiman. Pada perkembangannya, kawasan Pasar Ubud yang asli berkembang ke daerah sekitarnya. Area di sekitar Pasar Ubud yang berkembang menjadi area berjualan ini adalah koridor Jalan Karna. Koridor sepanjang kurang lebih 280 meter ini awalnya merupakan jalan permukiman. Lalu para pedagang mulai menggelar dagangannya di tepi jalan ini, sehingga koridor ini berkembang menjadi koridor komersial.

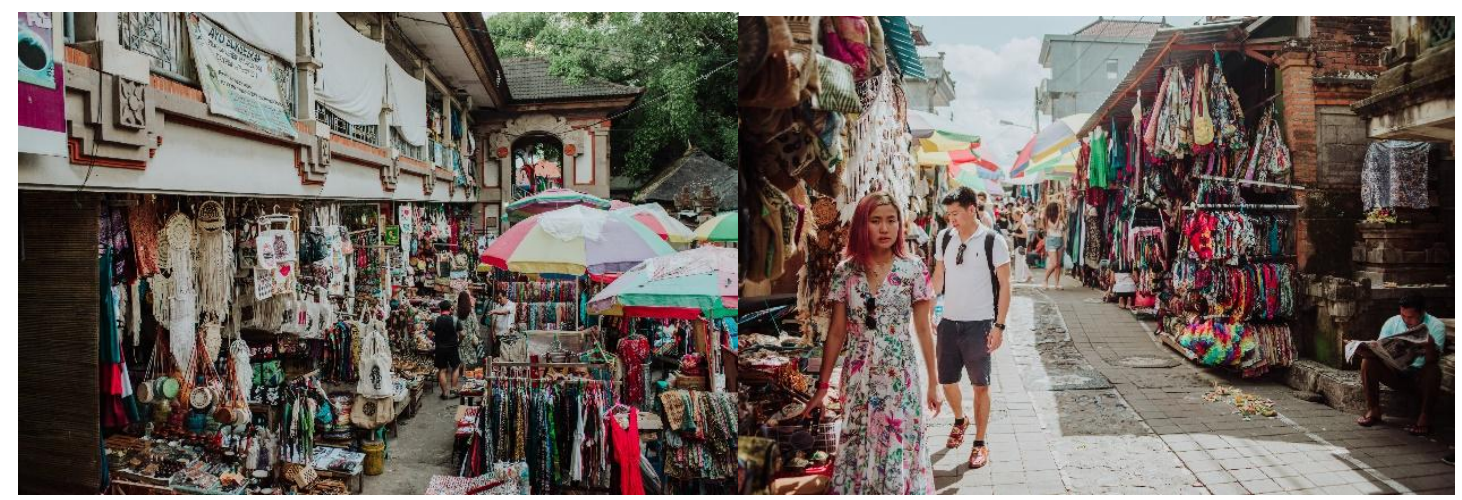

Gambar 1. Kawasan Pasar Ubud (kiri) dan korid or Jalan Karna (kanan)

Sumber: dokumentasi pribadi, 2018

\section{HASIL DAN PEMBAHASAN}

\section{A. Faktor Fisik Sense of Place Pasar Ubud}

Arsitektur, elemen-elemen di dalamnya, dan kawasan merupakan faktor fisik yang berpengaruh terhadap sense of place kawasan perbelanjaan (Kusumowidagdo, Sachari Widodo, 2012). Faktor-faktor fisik pembentuk sense of place pada Pasar Ubud meliputi arsitektur, kawasan, barang dagangan, vocal point, dan area berdagang. Faktor-faktor tersebut dijelaskan sebagai berikut.

\section{Arsitektur}

Elemen arsitektur yang membentuk sense of place Pasar Ubud meliputi pura dan pohon beringin, payung untuk peneduh area berjualan, gerbang area tangga bangunan pasar, signage area pasar dan pura dengan huruf Bali, perkerasan pada koridor pasar yang berundak, dan ornamen khas Bali pada bangunan pasar.

a. Pura dan beringin (keberadaan dan posisi)

Pura menjadi identitas yang khas pada setiap pasar di Bali. Unsur religius yang kuat pada masyarakat Hindu di Bali menjadikan setiap tempat umum mempunyai pura sebagai sarana bersembahyang bagi masyarakat, termasuk di Pasar Ubud. Pura menjadi area yang sangat penting di Pasar Ubud, terutama bagi para pedagang, karena para pedagang akan memulai aktivitasnya dengan bersembahyang di pura ini. Pohon beringin juga menjadi identitas yang khas pada setiap pasar di Bali, karena memiliki makna filosofis bahwa area di bawah pohon beringin merupakan area peneduh untuk aktivitas berjualan di pasar. 
"Setiap pasar di Bali pasti punya pura khusus pasar. Di setiap pasar di Bali pasti ada pohon beringin, maknanya untuk meneduhi orang yang berdagang di bawahnya. Di Pasar Ubud pura dan pasar terletak di samping pasar, tepatnya di seberang Puri Saren Agung." (A, penduduk lokal)

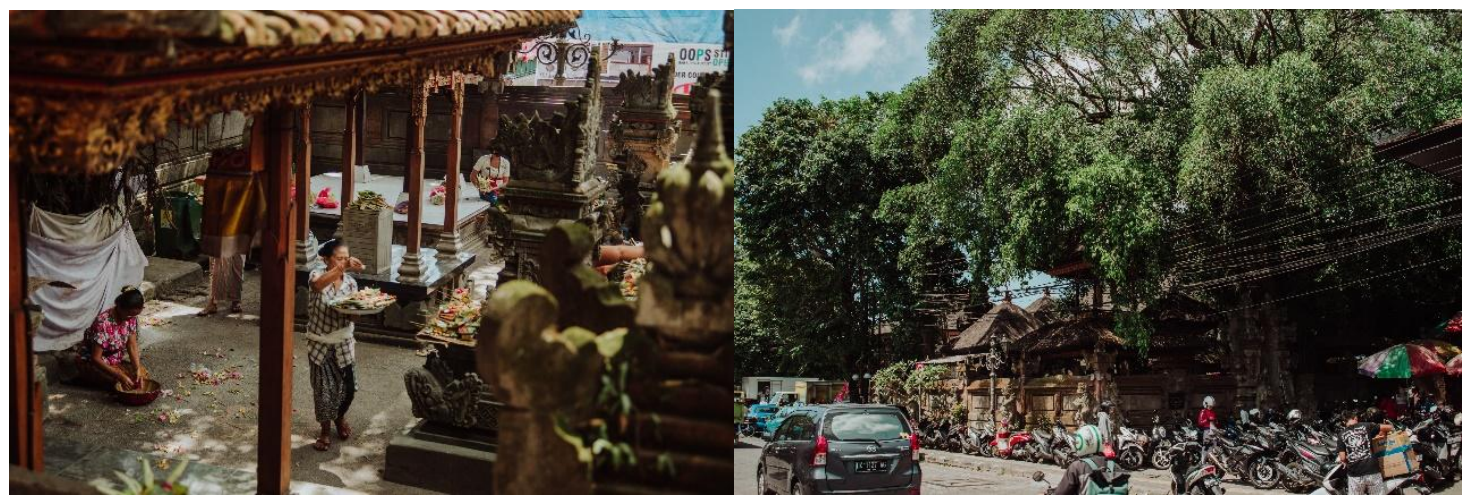

Gambar 2. Pura (kiri) dan pohon beringin (kanan) di kawasan Pasar Ubud Sumber: dokumentasi pribadi, 2018

b. Payung untuk peneduh area berjualan

Banyak pedagang memilih berjualan dan menggelar barang dagangannya di luar area bangunan, sehingga mengandalkan peneduh berupa payung. Fenomena ini ternyata sudah ada semenjak berdirinya Pasar Ubud, dapat terlihat dari lukisan pelukis ternama asal Ubud, Anak Agung Gde Sorbat, yang menggambarkan suasana Pasar Ubud pada masa lampau, dimana para pedagang mengandalkan peneduh berupa anyaman bambu pada area berdagangnya. Pada perkembangannya, anyaman bambu ini digantikan digantikan dengan payung atau terpal sebagai peneduh area berjualan.

"Peneduh untuk aktivitas pasar sudah ada sejak zaman dahulu, sebelum menggunakan payung, para pedagang dulunya menggunakan bedeng (anyaman bambu) untuk berteduh ketika menggelar dagangannya." (A, akademisi)

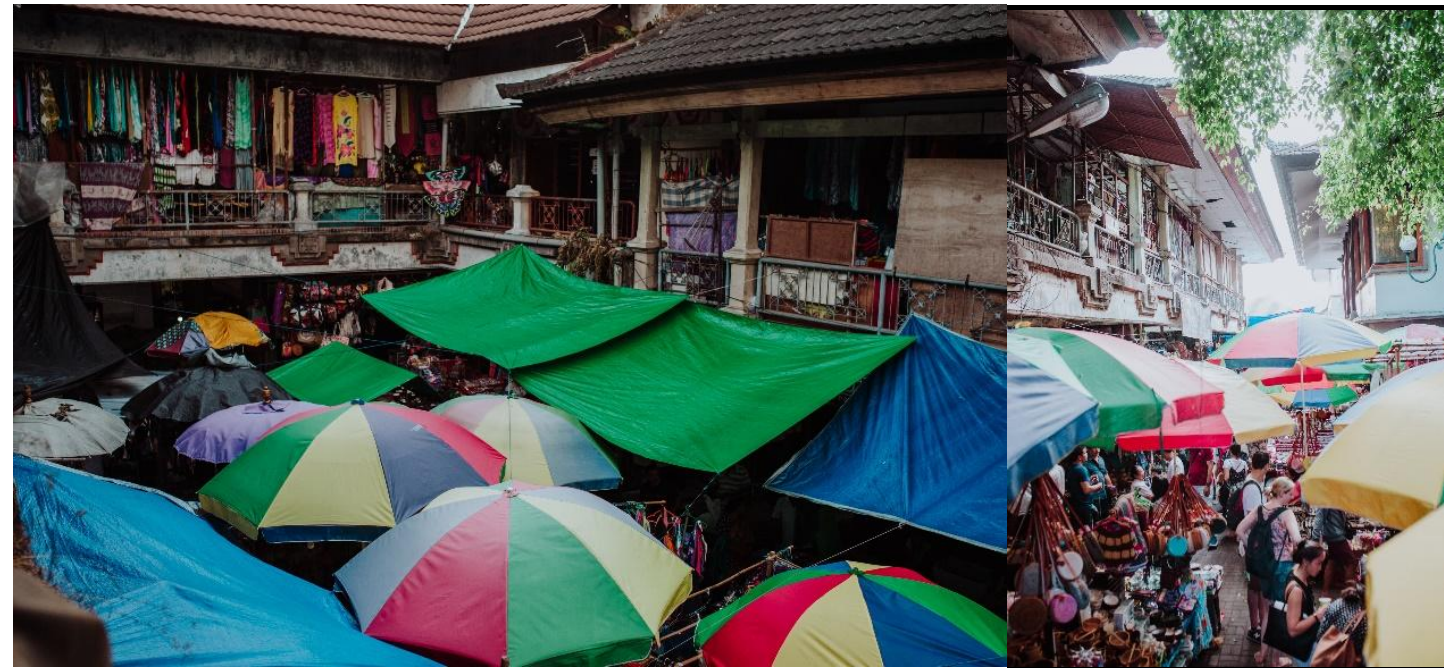

Gambar 3. Pen eduh payung pada area perdagangan di halaman pasar Sumber: dokumentasi pribadi, 2018 
c. Gerbang area tangga bangunan pasar

Gerbang ini sebenarnya merupakan akses menuju tangga untuk naik ke lantai dua bangunan pasar, yang dilengkapi dengan detail ornamen khas bangunan Bali. Pada bangunan pasar, gerbang ini menjadi kekhasan karena dimensinya yang besar dan terlihat dari jauh ketika memasuki kawasan pasar. Banyak pengunjung yang mengabadikan gambar gerbang ini melalui foto sebagai tanda bahwa mereka sudah pernah mengunjungi Pasar Ubud.

"Terdapat dua area lengkung dengan ornamen Bali pada bangunan pasar untuk menuju ke lantai dua." (M, pengunjung)

d. Signage area pasar dan pura dengan huruf Bali

Penanda pura Pasar Ubud diperlihatkan dengan signage nama pura yang ditulis dalam aksara Bali. Penanda dengan aksara asal daerah menunjukkan kekhasan suatu tempat. Peran signage untuk memberikan kejelasan penunjuk arah telah dikemukakan oleh Baker (1986), D’ Astous (2000), Wee dan Tong (2007), dan Boon (2011). Signage beraksara Bali ini masih dipertahankan untuk menunjukkan identitas Pasar Ubud yang berlokasi di Bali.

"Tempat umum di Bali khas dengan signage beraksara Bali, penanda seperti ini juga terdapat di Pasar Ubud." (M, pengunjung)

e. Perkerasan pada koridor pasar yang berundak

Kontur kawasan yang tidak rata menyebabkan ada area perkerasan yang dibuat berundak pada salah satu koridor pasar, koridor ini menjadi keunikan tersendiri dan di tepi jalannya banyak dimanfaatkan pedagang untuk mendisplay barang dagangannya. Area ini agak tersembunyi, tetapi banyak dicari oleh pengunjung untuk dapat melihat suasana Pasar Ubud dari posisi yang lebih tinggi.

"Area menanjak di samping pasar sangat menarik." (D, pengunjung)

f. Ornamen khas Bali pada bangunan pasar

Ornamen seperti ukiran dan dekorasi dari batu bata Bali pada bangunan pasar menjadi kekhasan Pasar Ubud. Ornamen ini banyak terdapat pada dinding bagian fasad bangunan dan juga terdapat pada area entrance atau gerbang menuju bangunan pasar. Ornamen Bali pada fasad bangunan berupa motif tumbuhan seperti bunga atau daun. Motif ini biasa disebut kekarangan, yaitu motif yang mengambil unsur-unsur alam, biasanya diletakkan pada bagian sudut atau tengah bangunan. Adanya ornamen ini membedakan bangunan pasar dengan bangunan permukiman di sekitarnya.

"Ornamen Bali merupakan kekhasan pada bangunan-bangunan publik di Ubud." (A, pengunjung)

\section{Kawasan}

Kawasan Pasar Ubud yang membentuk sense of place-nya meliputi lokasi pasar yang dekat dengan perempatan dan puri kerajaan serta batas area komersil yang membaur dengan permukiman sekitar.

a. Lokasi pasar dekat perempatan dan puri kerajaan

Pada pembagian area kerajaan di Bali, pasar selalu berada di dekat istana kerajaan dan terletak di salah satu sisi perempatan jalan. Begitu pula Pasar Ubud, lokasinya dekat dengan Puri Saren Agung, istana kerajaan Ubud dan dekat pula dengan area perempatan jalan yang saat ini dikenal dengan area Ubud Center. Pada masa lampau, lokasi pasar yang dekat dengan Puri Saren Agung ini merupakan sarana yang dibangun oleh raja Ubud untuk memfasilitasi kebutuhan rakyatnya serta berfungsi untuk memusatkan kegiatan dari masyarakat Ubud. Pada masa ini, lokasinya yang dekat dengan Puri Saren Agung sebagai 
tempat wisata di Ubud selalu menimbulkan ketertarikan pengunjung untuk mengunjungi pula Pasar Ubud.

"Di Bali, posisi pasar pasti dekat dengan kerajaan atau puri." (A, akademisi)

b. Batas area komersil yang membaur dengan permukiman sekitar

Pada perkembangannya Pasar Ubud yang lokasinya berdekatan dengan permukiman penduduk menjadikan area permukiman di sekitarnya menjadi area display barang dagangan, sehingga batas area antara pasar dengan permukiman menjadi baur. Banyak pedagang juga menggelar dagangannya di area pinggir jalan atau koridor menuju permukiman warga. Batasan yang membaur ini, meskipun acapkali menjadi masalah karena menimbulkan kemacetan pada area jalan di sisi pasar, juga menjadi kesempatan bagi penduduk sekitar pasar untuk mendisplay dan menjual dagangannya di area Pasar Ubud.

"Posisi pedagang pasar tradisional sampai menutupi satu jalur di sepanjang jalan area depan Puri Saren" (J, penduduk lokal Ubud)

\section{Barang Dagangan}

Barang dagangan saat pagi hari adalah kebutuhan pokok rumah tangga bagi masyarakat di sekitar Ubud. Kekhasan dari barang dagangan di pasar ini yaitu dijualnya peralatan dan bahan sembahyang, berupa bunga, dan keranjang banten (tempat sesaji) yang terbuat dari janur. Pada siang hingga sore hari barang dagangan yang dijual beralih menjadi barang-barang seni, seperti lukisan, patung, dan ukiran kayu, serta barang-barang yang sedang tren, seperti produk fesyen dan pernak-pernik souvenir, untuk menarik perhatian turis. Sangat beragamnya barang dagangan yang dijual oleh para pedagang menarik pengunjung untuk datang pada dua sesi, yaitu pagi dan siang hari sekaligus di pasar ini.

"Pagi hari Pasar Ubud digunakan untuk kegiatan pasar umum, yaitu menjual sembako. Aktivitas penjualan barang-barang seni dilakukan di pelataran setelah pasar pagi menutup dagangannya pukul 7 pagi." (N, pegawai Pasar Ubud)

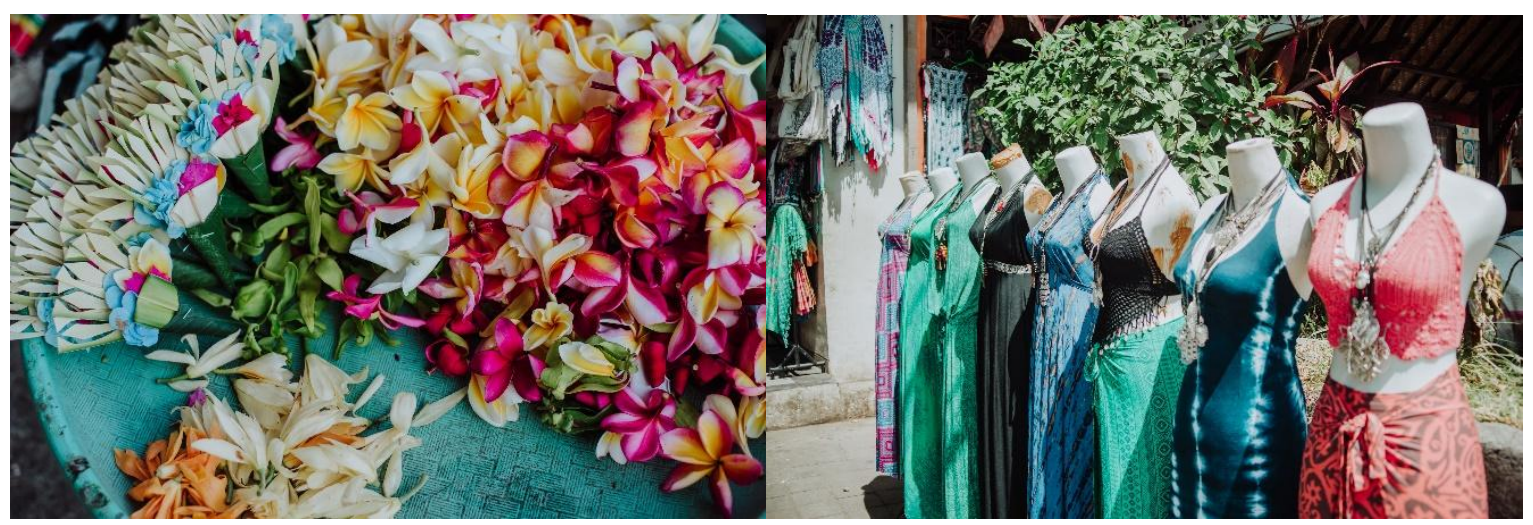

Gambar 4. Perbedaan jenis barang dagangan pagi (kiri) dan siang hari (kanan) di Pasar Ubud Sumber: dokumentasi pribadi, 2018

\section{Vocal point}

Banyak warga Ubud meletakkan peralatan sembahyang pada berbagai tempat umum di kawasan Pasar Ubud. Banyak sesaji dan banten diletakkan oleh para pedagang setelah sembahyang sebelum memulai aktivitas berjualan dan dapat terlihat dengan mudah oleh para pengunjung. Sesaji dan banten ini menjadi vocal point yang dapat dijumpai pengunjung di Pasar Ubud.

"Setiap pedagang pasti sembahyang sebelum berjualan, maka dari itu terdapat banten di banyak tempat di pasar." (A, penduduk lokal) 


\section{Area berdagang dengan mobil bak terbuka}

Pada sesi pasar pagi hari, barang dagangan berupa sayur dan buah kebanyakan diangkut sekaligus dijual pada mobil bak terbuka. Mobil-mobil bak terbuka ini terparkir secara rapi di sepanjang jalan di depan area pasar dan menutupi hampir separuh area jalan. Komposisi mobil mobil tersebut saat terparkir dan berbagai macam produk dagangan di atasnya dianggap menarik secara visual bagi pengunjung dan menimbulkan kekhasan tersendiri di Pasar Ubud. "Pedagang bermobil di pasar tradisional sampai menutupi satu jalur di sepanjang jalan depan Puri Saren, jam 7 pagi sudah bubar." (J, penduduk lokal)

\section{B. Faktor Sosial Sense of Place Pasar Ubud}

Selain faktor fisik, faktor sosial juga berpengaruh dalam membentuk sense of place Pasar Ubud. Faktor sosial tersebut meliputi histori, simbol pohon beringin, karakter pedagang dan pengunjung, serta aktivitas perdagangan dan transisi.

\section{Histori}

Kisah histori menjadi latar belakang terbentuknya suasana yang khas di Pasar Ubud. Memori dan histori dari suatu tempat menjadi faktor yang signifikan dalam pembentukan sense of place seperti diungkapkan Najafi \& Shariff (2011). Awalnya kegiatan di Pasar Ubud hanya ada setiap tiga hari sekali pada hari pasah (pasaran). Seiring perkembangan, kegiatan di pasar ini berlangsung setiap hari. Pasar Ubud berkembang menjadi pasar seni sejak wisatawan berkunjung di kawasan Ubud. Kawasan ini mulai berkembang sebagai pusat kegiatan seni karena banyaknya seniman yang hidup di Ubud. Para seniman ini awalnya berkarya membuat karya seni untuk upacara adat. Kedatangan wisatawan asing juga berpengaruh pada karya seni para seniman. Para seniman yang pada awalnya membuat karya seni dua dimensi mulai beralih membuat karya seni tiga dimensi. Pada tahun 1930-an karya seni berupa lukisan mulai dijual, sebagian karya ini dijual di Pasar Ubud. Histori ini menjadikan Pasar Ubud terkenal sebagai pusat perdagangan lukisan dan kaya seni di Bali.

"Pasar Ubud mulai menjadi pasar seni sejak ada wisatawan ke Ubud. Seniman tadinya membuat karya seni untuk upacara, lalu berkembang untuk dijual." (A, akademisi)

\section{Simbol Pohon Beringin}

Keberadaan pohon beringin di Pasar Ubud mempunyai makna filosofi yang dalam bagi masyarakat Ubud. Hal ini menjadikan pohon beringin menjadi identitas yang kuat di Pasar Ubud dan sangat dipertahankan keberadaannya oleh masyarakat Ubud. Pohon beringin ini dianggap suci dan merupakan bagian dari upacara Memukur bagi penganut agama Hindu di Ubud. Seperti dijelaskan oleh (Hashemnezhad, Heidari, and A Mohammad Hoseini 2013), faktor simbol budaya berkontribusi dalam kekhasan sebuah tempat.

"Pohon beringin di Pasar Ubud secara khusus digunakan untuk upacara ngangget don bingin (memetik daun beringin). Pada upacara ini bambu dan pisau yang digunakan untuk memetik daun pohon beringin harus disucikan dahulu, daun yang dipetik tidak boleh jatuh ke tanah dan harus ditampung dengan tikar." (A, akademisi)

\section{Karakter Pedagang dan Pengunjung}

Interaksi, aktivitas, dan karakter khas dari pengunjung dan pedagang menjadi pembentuk sense of place pada Pasar Ubud, hal ini seperti diungkapkan Kusumowidagdo dan Kusuma Wardhani (2017). Faktor karakter pedagang dan pengunjung ini sebetulnya dijumpai pula pada koridor Jalan Karna. Lebih detail, karakter pedagang dan pengunjung Pasar Ubud dijelaskan sebagai berikut.

a. Aktivitas sembahyang para penjual

Kekhasan karakter pedagang yang dapat dilihat di Pasar Ubud yaitu para pedagang biasanya bersembahyang di pura sebelum mulai berjualan. Aktivitas sembahyang ini 
bermakna memohon berkat dan perlindungan sepanjang hari itu agar kegiatan dan rejekinya selalu dilancarkan. Aktivitas ini juga ditandai dari banyaknya sesaji dan tempat sembahyang yang ada di sekitar kawasan Pasar Ubud.

"Bersembahyang merupakan aktivitas yang biasa dilakukan para pedagang sebelum berjualan." (A, penduduk lokal)

b. Logat dan Bahasa daerah setempat para penjualnya serta etnis pedagangnya

Para pedagang di Pasar Ubud mayoritas merupakan penduduk asli Bali, sehingga logat dan bahasa yang digunakan untuk berkomunikasi adalah Bahasa Bali. Seiring dengan banyaknya turis asing yang berkunjung, banyak penjual yang semakin fasih menggunakan bahasa asing untuk berkomunikasi dengan turis dari mancanegara.

"Pedagang Pasar Ubud biasanya berasal dari daerah di sekitarnya dan banyak yang secara turun temurun menjadi pedagang." (A, akademisi)

c. Pengunjung turis asing

Banyak pengunjung Pasar Ubud merupakan turis asing, fenomena ini menjadi pembeda dari pasar biasa yang hanya dikunjungi penduduk lokal, terutama saat sesi pasar seni (siang hingga sore hari). Kedatangan pengunjung turis asing ini membawa pengaruh pada Pasar Ubud yang awalnya hanya pasar tradisional hingga berkembang menjadi pasar seni.

"Pasar Ubud mulai menjadi pasar seni sejak ada wisatawan asing." (A, akademisi)

d. Penjual yang menyunggi keranjang barang dagangan di atas kepala

Di Pasar Ubud masih banyak ditemui ibu-ibu yang membawa barang dagangannya dengan cara dimasukkan dalam keranjang bambu, kemudian disunggi di atas kepala. Di pasar ini juga terdapat ibu-ibu yang berprofesi menawarkan jasa angkut barang belanjaan kepada para pengunjung menggunakan keranjang di atas kepala, yang biasa disebut tukang suun.

"Masih banyak penjual terutama ibu-ibu yang menjual buah dan sayur memakai suunan, (alas keranjang di kepala)." (J, penduduk lokal)

e. Pakaian khas

Masih banyak penjual dalam melakukan aktivitasnya di Pasar Ubud, terutama kaum ibu, menggunakan pakaian tradisional khas Bali seperti kain sarung. Para penjual ini juga menggunakan kain tradisional pada saat sembahyang sebelum memulai aktivitas perdagangan.

"Ibu-ibu terutama penjual buah, masih ada yang memakai baju tradisional." (J, penduduk lokal)

\section{Aktivitas Perdagangan dan Transisi}

Ada dua fungsi pasar yang berbeda setiap harinya, yaitu pasar umum saat pagi hari dan pasar seni pada siang hingga sore hari. Pasar pagi dibatasi sampai pukul tujuh pagi sehingga terjadi aktivitas yang khas di setiap harinya yaitu aktivitas saat transisi dari pasar pagi menjadi pasar seni, yang dimulai pada pukul 10 pagi hingga sore hari. Aktivitas yang berbeda ini menjadi perhatian pengunjung karena pengunjung harus mengetahui jadwal ini, tergantung dari apa yang dicarinya, kebutuhan sehari-hari atau barang seni.

"Pasar tradisional bubar jam 7 pagi, jam 8 sudah sepi. Pagi pasar tradisional, mulai berganti menjadi pasar seni jam 9-10." (J, penduduk lokal) 


\section{Faktor Fisik Sense of Place Koridor Jalan Karna}

Menurut Zacharias (1997), Zacharias (2002), Kusumowidagdo dan Kusuma Wardhani (2018), arsitektur, dimensi koridor, dan suasana yang terbentuk pada koridor menjadi faktor fisik yang berpengaruh pada sense of place koridor. Faktor fisik yang membentuk sense of place koridor Jalan Karna meliputi arsitektur, kawasan, urban interior, barang dagangan, dan vocal point.

\section{Arsitektur}

Pada koridor Jalan karna, elemen arsitektur yang membentuk sense of place-nya meliputi motif perkerasan lantai khas Bali, ornamen khas Bali pada permukiman sekitar, payung untuk peneduh area berjualan, dan area koridor jalan yang membaur antara pejalan kaki dan kendaraan bermotor.

a. Motif perkerasan lantai khas Bali

Jalan yang berkembang menjadi koridor belanja ini diperkuat dengan perkerasan jalan dengan motif khusus berupa ornamen bunga dan tumbuhan di sepanjang jalannya. Di ujung jalan menuju koridor diberi motif berupa tulisan yang menandakan area masuk koridor Jalan Karna. Motif perkerasan ini menjadi penanda yang khas untuk area koridor Jalan Karna bagi pengunjung.

"Koridor Jalan Karna mempunyai motif paving yang khas, menyesuaikan area jalan pengunjung." (M, pengunjung)

b. Ornamen khas Bali pada permukiman sekitar

Permukiman di sepanjang koridor Jalan Karna ini merupakan rumah tradisional Bali sehingga dapat dilihat detail ornamen Bali yang terdapat pada bangunannya. Pembatas area kanan kiri koridor didominasi oleh gerbang masuk, pagar, dan pura rumah warga. Secara organik, adanya ornamen Bali pada permukiman di sepanjang Jalan Karna menghadirkan identitas yang kuat khas Bali pada koridornya.

"Koridor ini menarik karena di sekitarnya rumah-rumah penduduk yang khas rumah Bali." (D, pengunjung)

c. Payung untuk peneduh area berjualan

Area berjualan yang tidak ada peneduh menyebabkan para pedagang membuat peneduh yang tidak permanen dari payung atau terpal. Deretan peneduh ini menimbulkan komposisi yang menarik bagi pengunjung ketika melewati koridor Jalan Karna.

d. Area koridor jalan yang membaur antara pejalan kaki dan kendaraan bermotor

Kondisi Jalan Karna merupakan jalan permukiman sehingga tidak ada larangan bagi kendaraan bermotor untuk melewati ataupun parkir di sepanjang jalan. Hal ini membuat tidak ada batasan yang jelas dan saling membaur antara area yang menjadi antara display dagangan, aktivitas jual beli, dan jalur pengunjung dengan jalur kendaraan bermotor.

"Jalan Karna sebenarnya tidak termasuk area Pasar Ubud." (N, pegawai Pasar Ubud) 


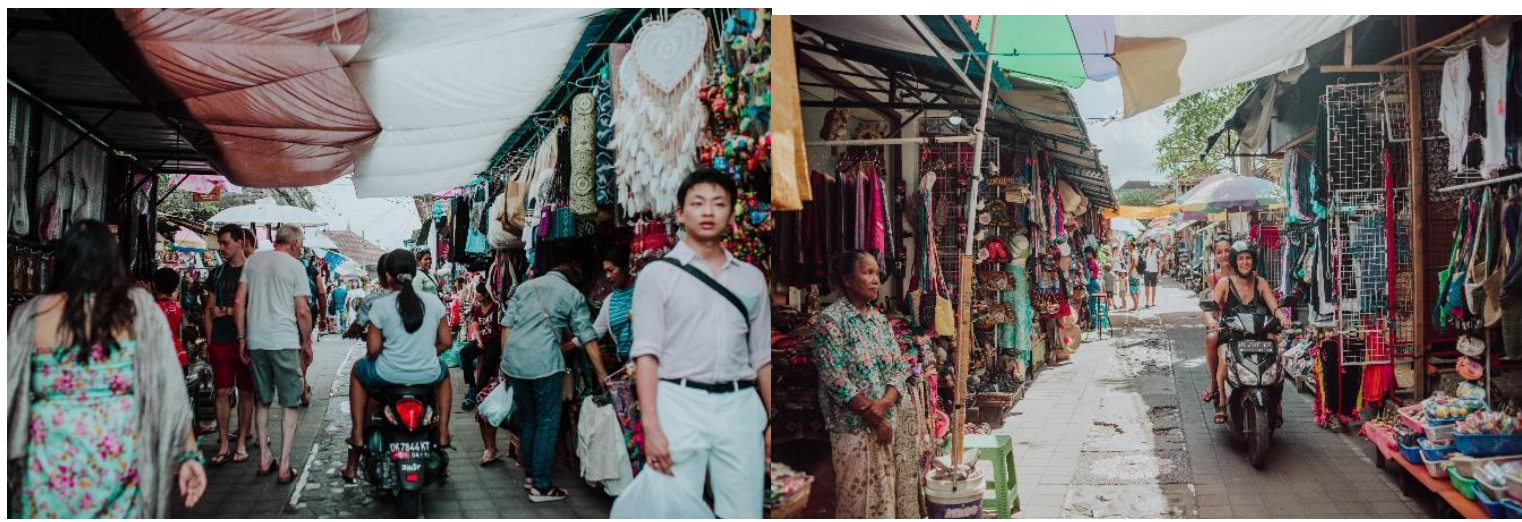

Gambar 5. Situasi Jalan Karna yang membaur antara aktivitas perdagangan dan jalan untuk kendaraan bermotor

Sumber: dokumentasi pribadi, 2018

\section{Kawasan}

Koridor Jalan Karna ini berada dekat dengan puri dan kerajaan dan merupakan jalan penghubung dari Pasar Ubud ke Lapangan Ubud. Keberadaannya menjadi penting karena semakin memperlihatkan struktur kawasan kerajaan di Bali, yaitu lokasi puri kerajaan akan selalu terhubung dengan pasar dan lapangan untuk berkumpul warganya. Seperti pada Pasar Ubud, kawasan Jalan Karna yang strategis ini berkembang menjadi lokasi yang menarik untuk dilewati oleh pengunjung.

"Pusat kerajaan di Bali pasti terdiri dari pasar, pura desa, lapangan, dan kantor kecamatan, begitu pula dengan Ubud." (A, penduduk lokal)

\section{Urban interior}

Koridor Jalan Karna merupakan ruang urban. Elemen arsitektur yang ada pada koridor itu, seperti payung, tenda-tenda, dan display barang dagangan yang cukup tinggi, menciptakan interioritas. Adanya elemen arsitektur yang melingkupi, seperti pada lantai, dinding, dan penutup atap, menyebabkan pengunjung bisa merasakan seakan-akan seperti di ruang interior, jika dibandingkan dengan ketika pengunjung melewati koridor jalan biasa.

"Adanya payung, tenda, display dagangan membuat orang yang lewat di antaranya serasa terlingkupi" (A, pengunjung)

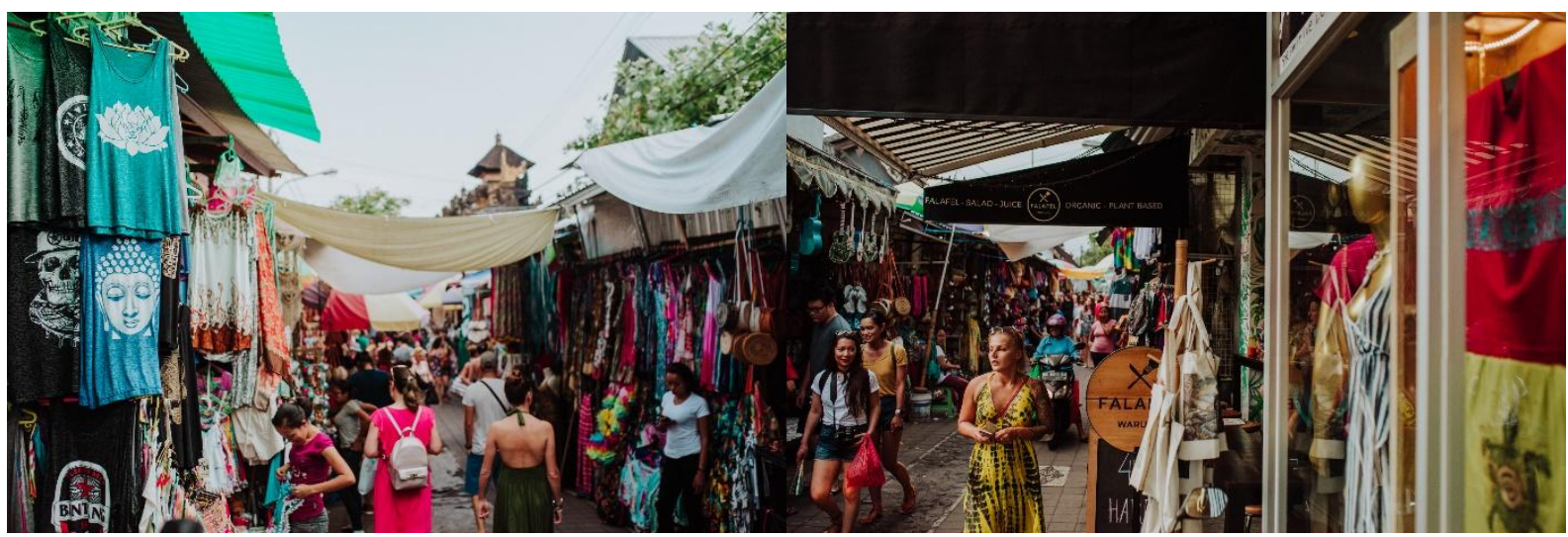

Gambar 6. Urban interior pada koridor Jalan Karna

Sumber: dokumentasi pribadi, 2018

\section{Barang dagangan}

Area koridor Jalan Karna yang merupakan perkembangan dari kawasan Pasar Ubud membuat barang dagangan yang dijual kurang lebih sama dengan barang dagangan di Pasar 
Ubud pada saat siang hari. Barang dagangan yang ditawarkan mayoritas berupa karya seni dan dan hasil kerajinan tangan, yang biasanya dicari pengunjung sebagai souvenir atau oleh-oleh.

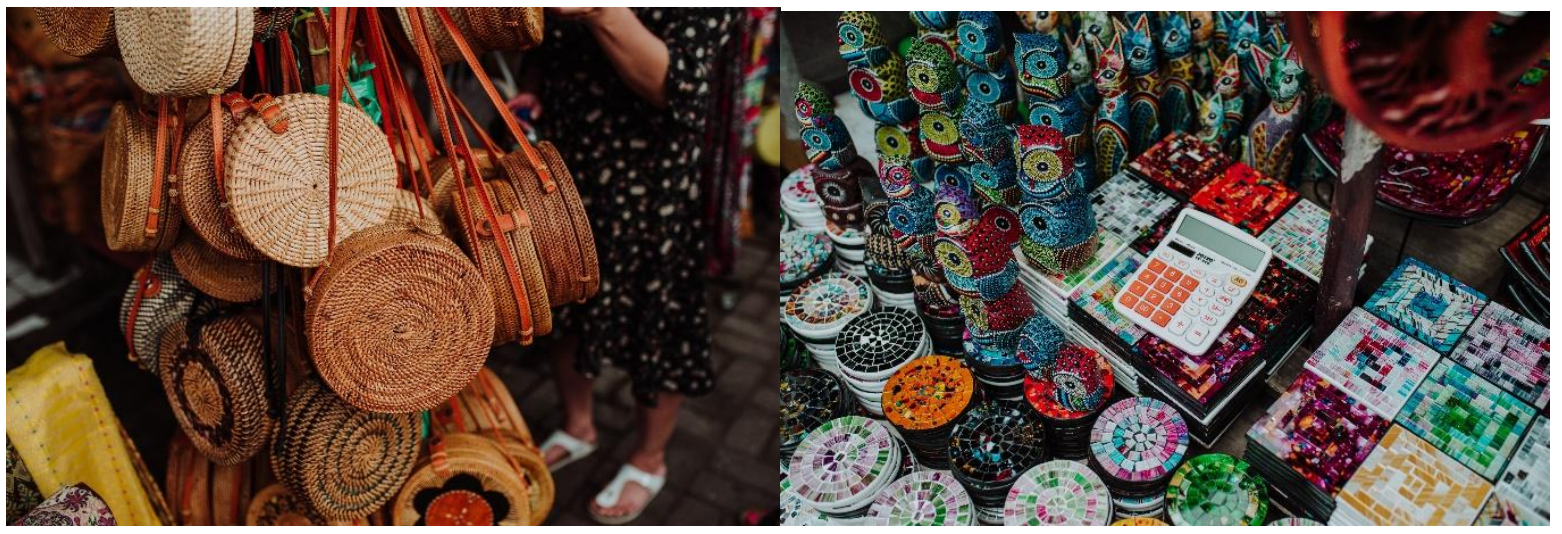

Gambar 7. Barang dagangan yang dijual di koridor Jalan Karna Sumber: dokumentasi pribadi, 2018

\section{Vocal point}

Lokasinya yang berada di antara kawasan permukiman membuat area sepanjang koridor Jalan Karna terlihat banyak sesaji dan tempat bersembahyang, terutama di depan rumah warga sekitar. Banyaknya simbol-simbol religius di area permukiman khas Bali ini membuat identitas tersendiri pada koridor ini yang banyak menarik perhatian pengunjung.

\section{Faktor Sosial Sense of Place Koridor Jalan Karna: Memori}

Karena lokasinya yang berdekatan dengan Pasar Ubud, faktor sosial yang membentuk sense of place koridor Jalan Karna pun hampir sama, terutama pada karakter pedagang dan pengunjungnya. Faktor sosial pembentuk sense of place koridor Jalan Karna yang membedakannya dari Pasar Ubud yaitu memori tempat tersebut. Selain karakter pedagang dan pengunjung, memori dari suatu tempat juga membentuk sense of place, seperti yang diungkapkan oleh Najafi \& Shariff (2011). Pada kawasan koridor Jalan Karna ini memori yang terekam yaitu pernah menjadi lokasi syuting film Eat, Pray, Love pada tahun 2009. Setelah kegiatan syuting itu banyak turis yang penasaran untuk mengunjungi koridor ini.

"Suasana Jalan Karna sama seperti di film Eat, Pray, Love" (D, pengunjung)

\section{KESIMPULAN}

Hasil penelitian menunjukkan faktor fisik yang membentuk sense of place di kawasan Pasar Ubud yaitu arsitektur, kawasan, barang dagangan, vocal point, dan area berdagang dengan mobil bak terbuka. Sedangkan faktor sosialnya berupa histori, simbol pohon beringin, karakter pedagang dan pengunjung, serta aktivitas perdagangan dan transisi. Sedangkan untuk koridor Jalan Karna, faktor fisik pembentuk sense of place-nya yaitu arsitektur, kawasan, urban interior, barang dagangan, dan vocal point. Sedangkan untuk faktor sosialnya yaitu memori dan karakter pedagang dan pengunjung. Untuk penelitian ke depan, dapat dikembangkan lebih lanjut dari metodenya, baik metode kuantitatif atau mixed method. Eksplorasi lokasi komersial wisata lainnya di berbagai daerah di Indonesia juga menjadi peluang yang menarik untuk memperdalam penelitian serupa.

Penelitian ini dapat terlaksana dengan adanya Hibah PTUPT dari Kemenristekdikti. Peneliti mengucapkan terima kasih untuk hibah tersebut, bantuan tim reviewer, pengelola jurnal ini, dan juga untuk LPPM Universitas Ciputra, para narasumber, serta tim PD Pasar Ubud. 


\section{DAFTAR REFERENSI}

Astuti, S., and H Hanan. 2011. "The Behaviour of Consumer Society in Consuming Food Restaurants and Cafes." Journal of Asian Behavioural Studies 1 (1): 72-83.

Baker, J. 2000. "The Role of the Environment in Marketing Services: The Consumer Perspective." The Services Challenge: Integrating for Competitive Advantage 1 (1): 79-84.

Bell, P.A, T Green, J. D Fisher, and A Baum. 1997. Environmental Psychology. New Jersey.

Boon, H. V. 2011. "Service Environments of Restaurants: Finsings from The Youth Customer." Journal of Asian Behavioural Studies 1 (2): 45-56.

Cross, J. E. 2000. "What Is Sense of Place?. Colorado State University. Libraries. d'Astous, A. "Irritating Aspects of the Shopping Environment." Journal of Business Research 49 (2): 149156.

D’Astous, A. 2000. "Irritating Aspects of the Shopping Environment." Journal of Business Research 49 (2): 149-56.

Hashemnezhad, H., A. Heidari, and P. A Mohammad Hoseini. 2013. "Sense of Place and Place Attachment." International Journal of Architecture and Urban Development 3 (1): 5-12.

J, Mitchell D, Kahn B E, and Knasko S C. 1995. "There's Something in The Air: Effect of Congruent or Incongruent Ambient Odor on Consumer Decision Making." Journal of Consumer Research 22 (1): 286-89.

Kramer, A. 2008. Retail Development. Washington DC: Urban Land Institute.

Kusumowidagdo, A, A Sachari, and P Widodo. 2012. "The Impact of Atmospheric Stimuli of Stores on Human Behavior." In Procedia-Social and Behavioral Sciences, 35:564-71.

- - _. 2015. "Visitors' Perception towards Public Space in Shopping Center in the Creation Sense of Place." In Procedia-Social and Behavioral Sciences, 184:266-72.

- - 2016. "Visitors' Perceptions on the Important Factors of Atrium Design in Shopping Centers: A Study of Gandaria City Mall and Ciputra World in Indonesia." Frontiers of Architectural Research 5 (1): 52-62.

-_- 2017. Investigating Sense of Place at Historic Commercial Street Corridor. Vsitor Perception of Social Aspects. UK: Taylor and Francis Group.

Najafi, M, and Shariff M. K. B M. 2011. "Studies, The Concept of Place, and Sense of Place in Architectural." International Journal of Human and Social Sciences 6 (3): 187-93.

Schulz, N. 1979. Genius Loci. New York: Rizzoli International.

Wardhani, D. K, and A Kusumowidagdo. 2018. Authenticity of the Physical Environment That Influences a Sense of Place: A Qualitative Study at Ampel Street Corridor, Surabaya, Indonesia. UK: Taylor and Francis Group.

Yin, R. K. 2011. Applications of Case Study Research. Sage.

Zacharias, J. 2002. "Choosing a Path in the Underground: Visual Information and Preference." In In ACUUS International Conference Urban Underground Space: A Resource for Cities. Torino.

Zacharias, J. 1997. "The Impact of Layout and Visual Stimuli on the Itineraries and The Perceptions of Pedestrians in Public Market." Environment and Planning: Planning and Design 23 (23): 55. 